
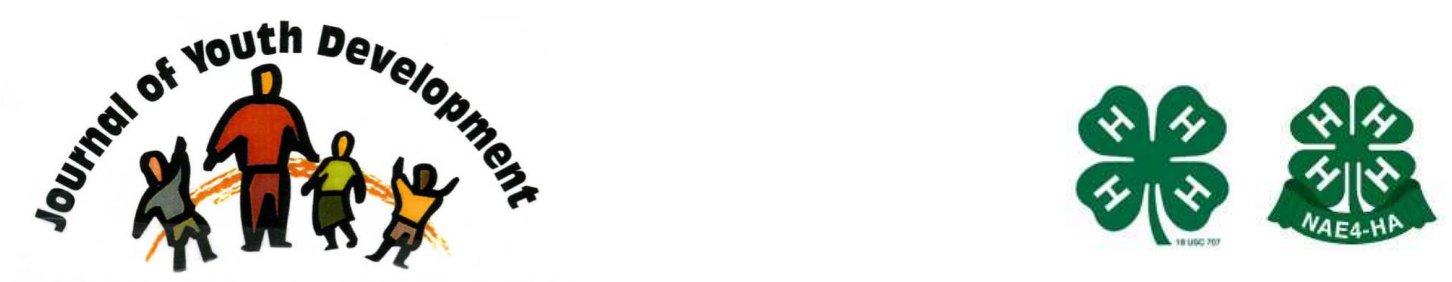

Bridging Research \& Practice

\title{
Overnights Encourage Girls' Interest in Science-Related Careers
}

Kimberly A. Christman

University of Illinois Extension

Freeport, IL

christma@uiuc.edu

Sara Hankemeier

University of Illinois Extension

Jo-Carroll County, Mt. Carroll, IL

hankenmei@uiuc.edu

Jennifer Hunter

University of Illinois Extension

Whiteside County, Morrison, IL

jmhunter@uiuc.edu

Johnna Jennings

University of Illinois Extension

DeKalb County, Sycamore, IL

jbjennin@uiuc.edu

Debbie Moser

University of Illinois Extension

Ogle County, Oregon, IL

dmoser@uiuc.edu

Sandy Stiles

University of Illinois Extension

Lee County, Amboy, IL

sstiles@uiuc.edu 


\section{JOURNAL OF YOUTH DEVELOPMENT \\ bridging research and practice

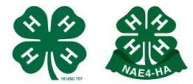

Volume 3, Number 1, Summer 2008

Article 080301PA001

\section{Overnights Encourage Girls' Interest in Science-Related Careers}

Kimberly A. Christman, Sara Hankemeier, Jennifer Hunter, Johnna Jennings,
Debbie Moser and Sandy Stiles
University of Illinois Extension

Abstract: With sell-out crowds and phenomenal research results, Science Siesta and Advanced Science Siesta are programs designed to change the traditional perceptions that girls have about science and science-related careers. Through hands-on science activities (in and out of the lab), and through working with local female scientists, girls who range from fourth to eighth grade are provided valuable opportunities to combat the stereotype that "girls can't do science." This article addresses the need to engage girls in science and explains "how-to" meet that need through the Science Siesta programs.

\section{Introduction}

Though jobs requiring advanced degrees in science and math continue to flourish, women remain underrepresented in these careers (Bordogna, 2003). It is unfortunate to note that even though women make up about $50 \%$ of the United States workforce, they account for only about $21 \%$ of the nation's scientists and $11 \%$ of the engineers (Ride Urges, 2006). Experts agree that this is a complex problem with no easy answers. However, they do point to some steps that can be taken to promote science-related careers among girls. These steps include:

- Encouraging girls to become involved in enrichment or summer programs that focus on science;

- Using non-sexist language and examples when teaching science;

- Utilizing female scientists as role models for young girls; and

- Creating an environment where hands-on learning is encouraged. (Five Myths, 2007 and Why Girls, 2005)

It was in the spirit of these suggestions that a program called Science Siesta was initiated by University of Illinois Extension Youth Development professionals in Northwest Illinois during the spring of 2002. The goal of this program was to begin changing the traditional perceptions that 
girls have had about science-related careers by providing them with unique opportunities to meet and interact with local female scientists; conduct fun, hands-on science activities in the lab; and participate in activities in stimulating science-centered environments.

\section{Program Design}

Reaching sell-out crowds annually, Science Siesta is now in its sixth year. The program targets girls in grades 4-6 and is a blend of "science" and "siesta". It is conducted by University of Illinois Extension Youth Development staff and is held at the Discovery Center Children's Museum and Burpee Museum of Natural History in Rockford, IL. A maximum of 160 girls can participate annually at the low rate of $\$ 30$ each. The cost includes program supplies, museum admission, science activities, pizza, an evening snack, breakfast, and a t-shirt. Remaining expenses are covered by grants and donations secured as needed.

Participants engage in a total of 7 hours of programming. During that timeframe, participants meet local female scientists representative of fields such as forensics, medicine, engineering, chemistry, meteorology, plant science, vet science, and more. Participants then engage in 20minute interactive workshops led by these scientists. After working with the scientists, participants are split into three groups where the girls complete hands-on lab activities that revolve around the work of a female scientist featured in University of Nebraska's "Wonderwise Women in Science Learning Series" curriculum. As the evening draws to a close, they enjoy free time to "play" among the host sites' exhibits.

When it is time for lights out, participants spread out their sleeping bags among the museum exhibits and sleep under the supervision of one of 16 high school and college-age counselors who have volunteered their time to assist with the leadership of the event.

\section{Program Evaluation}

Science Siesta is evaluated using a combination of instruments, including a pre-test, post-test, and evaluation. To date, the program has reached approximately 740 girls. Results from 2006 indicated that $96 \%$ of the girls who participated agreed Science Siesta had made them more aware of the variety of available science and math-related careers. Ninety-two percent credited Science Siesta with increasing their confidence in their abilities to do science. Eighty-nine percent agreed that the program had increased their interest in science and math-related careers.

\section{Expansion of Program}

Science Siesta expanded in 2006 to include a "graduate-level" opportunity for girls who had attended two or more times and were in the $7^{\text {th }}$ or $8^{\text {th }}$ grades. Dubbed Advanced Science Siesta, this program was the result of participant recommendations collected during a 2005 focus group study of multi-year participants.

Advanced Science Siesta was developed with the intent of taking the objectives of Science Siesta up a notch for past participants. The goal was to engage participants in more interactive field experiences that would encourage higher level thinking, application of knowledge of skills, and extended interest in science. Objectives included helping participants:

- Achieve a greater understanding of science careers;

- Develop science methodology skills; and

- Increase their life skills related to decision making, responsibility, using resources wisely, and developing marketable skills. 
During its inaugural year, Advanced Science Siesta involved Science Siesta graduates in indepth science activities at two sites in Dubuque, Iowa, one being at the National Mississippi River Museum and the other being the E.B. Lyons Interpretive Center. Immediately after school on Friday evening, forty girls boarded a bus and traveled to the National Mississippi River Museum for the first leg of their overnight experience. At the museum, they unloaded their personal belongings onto the William $\mathrm{H}$. Black, a retired dredge boat whose bunkroom was to serve as their sleeping accommodations. During the evening, Advanced Science Siesta participants enjoyed workshops led by museum staff that were focused on water conservation, soil erosion, and Mississippi mammals. They also experienced the multi-sensory video presentation of "Journey On The Mississippi."

The next morning, participants engaged in animal husbandry activities with museum staff as they prepared the many animal exhibits for the day. Participants also participated in a waterways erosion model activity, as well as learned about a variety of Mississippi River reptiles. In the afternoon, participants boarded the bus, and traveled to E.B. Lyons Interpretive Center for several hours of seining and testing the quality of the Mississippi backwaters, tagging monarch butterflies, and prairie study. Late in the afternoon, participants boarded the bus for the last time to begin their journey back home.

Advanced Science Siesta participants paid a $\$ 40$ registration fee that helped to cover program materials, lodging, museum admission, workshop costs, meals, and a program souvenir. Additional funding was made possible through a grant by the Community Foundation of Northern Illinois and the Lisa Woessner Science \& Technology Award given by the Illinois 4-H Foundation.

As with Science Siesta, an Institutional Review Board approved pre-test, post-test, and evaluation were given to participants to measure the program's success and impact. Results showed that participants believed the weekend was very valuable to them in terms of changing their perceptions and attitudes about science as a career option. Ninety-five percent indicated that Advanced Science Siesta showed them a different side of science. Ninety-eight percent said that the program helped them see how science can be used to solve problems our country faces. Ninety-eight percent agreed that "girls should consider careers in science," and $87 \%$ agreed that Advanced Science Siesta taught them that science is likely to be useful to them when they think about what kinds of jobs they'd like to have as an adult.

Advanced Science Siesta '07 is in its planning stages at this time, but promises to be even more intense than the '06 version. University of Illinois Extension Youth Development professionals are partnering with University of Illinois faculty in the Colleges of Engineering and Agricultural, Consumer, and Environmental Sciences to provide girls with incredible hands-on activities alongside actual researchers. "Real world" applications of careers in these fields will also be addressed.

\section{Replication}

Individuals wishing to emulate the Science Siesta or Advanced Science Siesta programs locally are invited to purchase a CD from University of Illinois Extension. The CD contains copies of the event schedules, registration materials, evaluation tools, website design, promotional materials, the t-shirt design, and more and is available at the cost of $\$ 15.00$. Mail a written request with payment to the University of Illinois Extension, Stephenson County, 2998 W. Pearl City Rd., Freeport, IL 61032. 


\section{References}

Bordogna, Joseph, Dr. (2003, January). Leveraging Experience to Accelerate Progress (LEAP): Moving Towards Gender Equity in Engineering. Speech given at National Science Foundation Education Conference, Washington, DC.

Five Myths About Girls and Science. (2007, October). Science Scope, Available at: http://www.nsf.gov/news/news summ.jsp?cntn id=109939

Ride Urges Emphasis On Math, Science Studies. (2006, March 19). USA Today. Retrieved March 19, 2006, from: http://www.usatoday.com/money/companies/management/2006-03-19-sallyride $\mathrm{x} \cdot \mathrm{htm}$ ?loc $=$ interstitialskip

Why Girls Bypass Science: Perceptions and Messages Steer Them Away. (2005, July). Industrial Engineer 37.7 16(2).

(c) Copyright of Journal of Youth Development $\sim$ Bridging Research and Practice. Content may not be copied or emailed to multiple sites or posted to a listserv without copyright holder's express written permission. However, users may print, download or email articles for individual use. 


\section{Appendix 1}

\section{SCIENCE SIESTA '07}

PRE-TEST / POST TEST

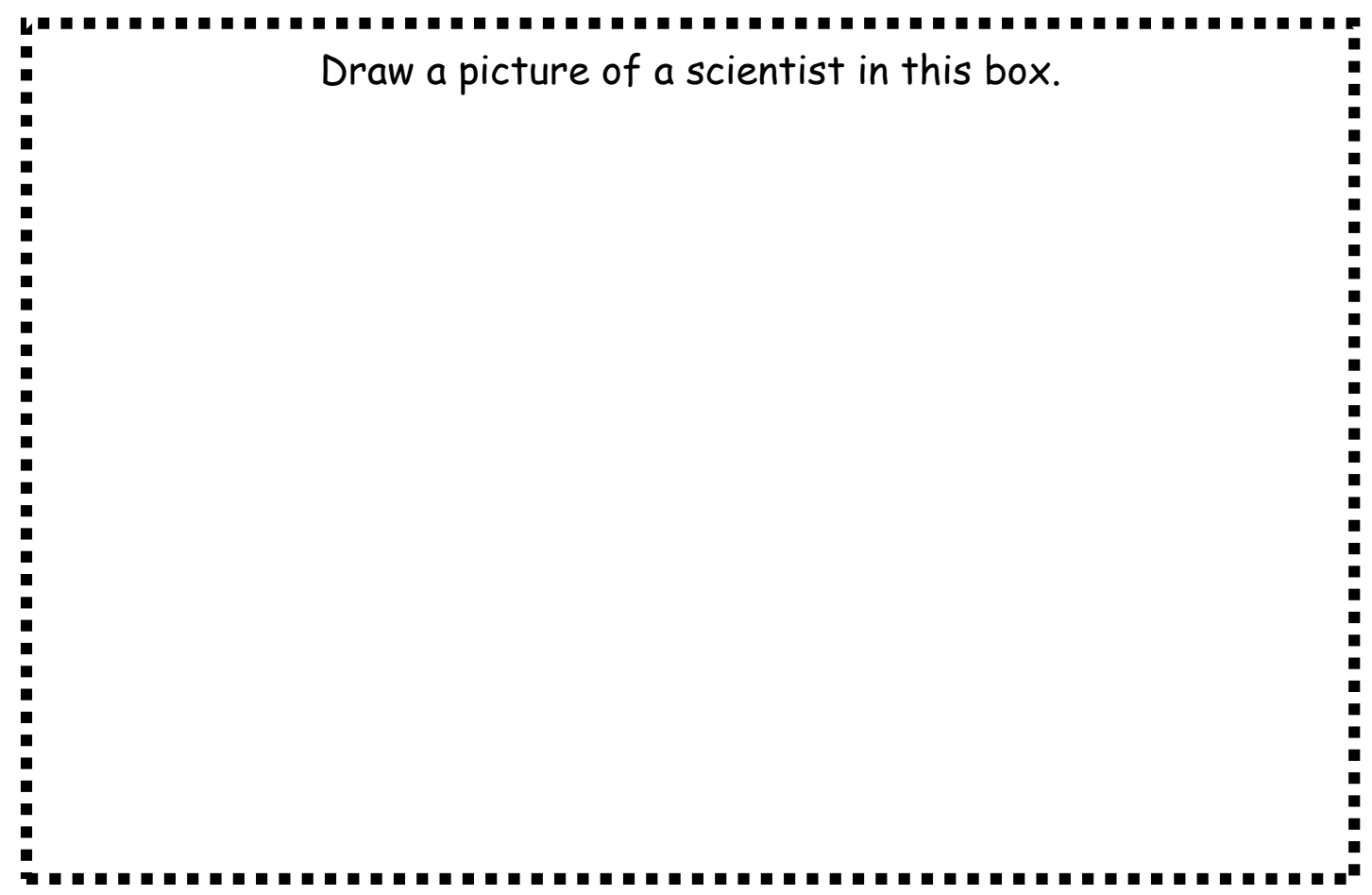

1. Put the steps of the scientific method in the correct order.

(Write \# 1 by the first step; \#2 by the second step, etc.)

Develop a hypothesis

State your theory

Conduct experiments

Make an observation

Ask a question

Make predictions

2. Why is it important to use the scientific method? 
3. Select the job description and cool fact that best describes each scientist. Put the letter of the correct response in the appropriate box.

\begin{tabular}{|l|l|l|}
\hline \multicolumn{1}{|c|}{ SCIENTIST } & JOB DESCRIPTION & A COOL FACT \\
\hline Analytical Chemist & & \\
\hline Coroner & & \\
\hline Nuclear Chemist & & \\
\hline Nurse & & \\
\hline Pharmacist & & \\
\hline Physical Therapist & & \\
\hline Plant Pathologist & & \\
\hline Safety Engineer & & \\
\hline Veterinarian & & \\
\hline
\end{tabular}

\section{CHOOSE FROM THESE JOB DESCRIPTIONS:}

A. Investigates deaths such as homicides, suicides, and traffic fatalities.

B. Prepares and dispenses drugs and knows about their properties.

C. Reviews aircraft systems to insure that takeoffs and landings will be safe.

D. Works to prevent diseases and treat sick animals of all kinds.

E. Protects the health and safety of the public by overseeing the equipment in her plant.

F. Invents and applies methods of determining the chemical make-up of substances.

G. A caregiver with knowledge about the physical and emotional needs of the people she serves.

$\mathrm{H}$. Helps people improve mobility, relieve pain, increase strength, and prevent deformity.

I. Studies plants, plant systems, and plant diseases. 


\section{CHOOSE FROM THESE COOL FACTS:}

J. This scientist uses mathematical equations to calculate the dosages of her patients medications.

K. Scientists in this field have discovered that the Salem "witches" were not witches at all! They were hallucinating from having eaten cereal contaminated with a fungal disease!

L. This scientist fills doctor's orders for both humans and animals.

M. Where this scientist works, power is generated by fuel rods containing thimble-sized pellets.

$\mathrm{N}$. This scientist deals with facts like: the human body contains $250 \mathrm{~g}$ ( $1 / 2$ pound) of salt.

O. This scientist works with individuals who do not speak English, so they must rely on body language to communicate.

P. Scientists in this field know there are 206 bones in the adult human body that can impact their work daily.

Q. This scientist is concerned with details like the fact that an empty Boeing 747-400 aircraft weighs 399,000 pounds.

R. This scientist gets paid to be nosey!

4. Answer one of the following multiple choice questions as it relates to your breakout session workshop. Circle the correct answer to the question.

Sea Otter Biologist Track

Pollen

Detective Track
Oil spills in waterways:

A. Affect the environment for only a few days after the spill

B. Affect the environment for up to one year after the spill

C. Affect the environment for one to five years after the spill

D. Affect the environment for an undetermined amount of time

Which of the following is NOT considered a pollinator?
A. Honeybees
B. Garden Spiders
C. Hawkmoths
D. Flower Beetles

\section{African \\ Plant Explorer Track}

If starch is present in food, what color will the iodine change during an iodine test?
A. Color will change from reddish brown to green
B. Color will change from reddish brown to blue-black
C. Color will change from reddish brown to orange
D. Color will change from reddish brown to pink 
Appendix 2

Post Program Evaluation

\begin{tabular}{|l|l|l|l|l|}
\hline & $\begin{array}{c}\text { Strongly } \\
\text { Agree }\end{array}$ & Agree & Disagree & $\begin{array}{l}\text { Strongly } \\
\text { Disagree }\end{array}$ \\
\hline $\begin{array}{l}\text { The Science Siesta weekend showed me a } \\
\text { different side of science }\end{array}$ & & & & \\
\hline $\begin{array}{l}\text { Based on this weekend, I expect to do better in } \\
\text { science at school }\end{array}$ & & & & \\
\hline This weekend increased my interest in science & & & & \\
\hline $\begin{array}{l}\text { This weekend helped me see how science can be } \\
\text { used to solve problems our country faces }\end{array}$ & & & & \\
\hline $\begin{array}{l}\text { The job shadowing (seeing what a museum staff } \\
\text { member does) gave me some ideas of what I } \\
\text { might like to do when I select a job }\end{array}$ & & & & \\
\hline $\begin{array}{l}\text { One of the things I learned this weekend is I am } \\
\text { definitely not interested in science }\end{array}$ & & & & \\
\hline $\begin{array}{l}\text { This weekend I learned science is not likely to be } \\
\text { useful to me when I think about what kind of job } \\
\text { I would like to have in later life. }\end{array}$ & & & & \\
\hline Girls should not consider careers in science. & & & & \\
\hline Boys are better than girls in science. & & & & \\
\hline
\end{tabular}

\begin{tabular}{|c|c|c|c|c|}
\hline $\begin{array}{l}\text { Please circle a number showing how much you } \\
\text { learned from the Science Siesta Weekend }\end{array}$ & $\begin{array}{l}\text { Learnec } \\
\text { Little or } \\
\text { Nothing }\end{array}$ & & & $\begin{array}{c}\text { Learned a } \\
\text { Great } \\
\text { Deal }\end{array}$ \\
\hline How science is useful in solving problems & 1 & 2 & 3 & 4 \\
\hline How scientists work outside a laboratory & 1 & 2 & 3 & 4 \\
\hline $\begin{array}{l}\text { How much did you learn from the Mississippi River } \\
\text { Journey? (movie) }\end{array}$ & 1 & 2 & 3 & 4 \\
\hline $\begin{array}{l}\text { How much did you learn from your behind the } \\
\text { scenes tour of animal husbandry? }\end{array}$ & 1 & 2 & 3 & 4 \\
\hline $\begin{array}{l}\text { How much did you learn from the study of reptiles } \\
\text { and amphibians? }\end{array}$ & 1 & 2 & 3 & 4 \\
\hline $\begin{array}{l}\text { How much did you learn from mammal } \\
\text { identification? }\end{array}$ & 1 & 2 & 3 & 4 \\
\hline $\begin{array}{l}\text { How much did you learn from envioroscape } \\
\text { model? }\end{array}$ & 1 & 2 & 3 & 4 \\
\hline How much did you learn from invertebrate count? & 1 & 2 & 3 & 4 \\
\hline $\begin{array}{l}\text { How much did you learn from water } \\
\text { sampling/testing }\end{array}$ & 1 & 2 & 3 & 4 \\
\hline $\begin{array}{l}\text { How much did you learn about the ecosystem in a } \\
\text { Prairie? }\end{array}$ & 1 & 2 & 3 & 4 \\
\hline $\begin{array}{l}\text { How much did you learn about tagging monarch } \\
\text { butterflies? }\end{array}$ & 1 & 2 & 3 & 4 \\
\hline
\end{tabular}


Opinion. Indicate your true feelings, not what you think may be an answer that is expected. Circle the appropriate answer according to the scale below. It is important that all questions are answered by circling only one number.
1. Strongly Agree
2. Agree
3. Mildly Agree
4. Mildly Disagree
5. Disagree
6. Strongly Disagree

PART A consists of statements numbered 1 to 32 which complete the following sentence:

When I think about a scientist, I think of a person who:

Circle ONE number

1. Sits in a laboratory all day.

2. Pours chemicals from one test tube to another.

3. Takes his/her work seriously.

4. Is considered just a small part in a machine, if he/she works for a large corporation. $\begin{array}{lllllll}1 & 2 & 3 & 4 & 5 & 6\end{array}$

5. Is courageous.

$\begin{array}{llllll}1 & 2 & 3 & 4 & 5 & 6\end{array}$

6. Believes that there is no God.

$\begin{array}{llllll}1 & 2 & 3 & 4 & 5 & 6\end{array}$

7. Is open minded.

$\begin{array}{llllll}1 & 2 & 3 & 4 & 5 & 6\end{array}$

8. Is so involved in work that he/she doesn't know what's happening in the world.

$\begin{array}{llllll}1 & 2 & 3 & 4 & 5 & 6\end{array}$

9. Records data carefully.

10. Uses words few people understand.

$\begin{array}{llllll}1 & 2 & 3 & 4 & 5 & 6\end{array}$

11. Is dedicated.

12. Is usually reading a book.

13. Does not work for money, fame or self-glory.

14. Works for the benefit of human kind.

15. Is intelligent.

16. Has spent many years studying.

17. Works in a dreary laboratory.

18. Has heavy expenses if he/she works alone.

19. Is careful in his/her work.

20. Is patient.

21. Must keep secrets if he/she works for the government.

22. Knows his/her subject.

23. Neglects his/her family.

24. Has little social life.

25. Stands up for his/her ideas when attacked.

26. Has few hobbies or means of relaxation.

27. Is prepared to work long hours.

28. Is prepared to work years without getting results.

29. Is rarely home.

30. May work for years without success.

31. Works at an uninteresting job.

32. Makes the world a better place to live. $\begin{array}{llllll}1 & 2 & 3 & 4 & 5 & 6\end{array}$

$\begin{array}{llllll}1 & 2 & 3 & 4 & 5 & 6\end{array}$

$\begin{array}{llllll}1 & 2 & 3 & 4 & 5 & 6\end{array}$

$\begin{array}{llllll}1 & 2 & 3 & 4 & 5 & 6\end{array}$

$\begin{array}{llllll}1 & 2 & 3 & 4 & 5 & 6\end{array}$

$\begin{array}{llllll}1 & 2 & 3 & 4 & 5 & 6\end{array}$

$\begin{array}{llllll}1 & 2 & 3 & 4 & 5 & 6\end{array}$

$\begin{array}{llllll}1 & 2 & 3 & 4 & 5 & 6\end{array}$

$\begin{array}{llllll}1 & 2 & 3 & 4 & 5 & 6\end{array}$

$\begin{array}{llllll}1 & 2 & 3 & 4 & 5 & 6\end{array}$

$\begin{array}{llllll}1 & 2 & 3 & 4 & 5 & 6\end{array}$

$\begin{array}{llllll}1 & 2 & 3 & 4 & 5 & 6\end{array}$

$\begin{array}{llllll}1 & 2 & 3 & 4 & 5 & 6\end{array}$

$\begin{array}{llllll}1 & 2 & 3 & 4 & 5 & 6\end{array}$

$\begin{array}{llllll}1 & 2 & 3 & 4 & 5 & 6\end{array}$

$\begin{array}{llllll}1 & 2 & 3 & 4 & 5 & 6\end{array}$

$\begin{array}{llllll}1 & 2 & 3 & 4 & 5 & 6\end{array}$

$\begin{array}{llllll}1 & 2 & 3 & 4 & 5 & 6\end{array}$

$\begin{array}{llllll}1 & 2 & 3 & 4 & 5 & 6\end{array}$

$\begin{array}{llllll}1 & 2 & 3 & 4 & 5 & 6\end{array}$

$\begin{array}{llllll}1 & 2 & 3 & 4 & 5 & 6\end{array}$

$\begin{array}{llllll}1 & 2 & 3 & 4 & 5 & 6\end{array}$

$\begin{array}{llllll}1 & 2 & 3 & 4 & 5 & 6\end{array}$ 
1. Strongly Agree

2. Agree

3. Mildly Agree

4. Mildly Disagree

5. Disagree

6. Strongly Disagree

PART B consists of complete statements numbered 33 to 48 .

33. A scientist's work is dangerous.

$\begin{array}{llllll}1 & 2 & 3 & 4 & 5 & 6\end{array}$

34. I would like to be a scientist.

12534456

35. Science is responsible for causing pollution.

$\begin{array}{llllll}1 & 2 & 3 & 4 & 5 & 6\end{array}$

36. Scientists are good for society because they help find cures.

$\begin{array}{llllll}1 & 2 & 3 & 4 & 5 & 6\end{array}$

37. Science is responsible for wars.

38. Science is necessary for the defense of our country.

$\begin{array}{llllll}1 & 2 & 3 & 4 & 5 & 6\end{array}$

39. I would like to marry a scientist.

$\begin{array}{llllll}1 & 2 & 3 & 4 & 5 & 6\end{array}$

40. We would be better off without scientists.

$\begin{array}{llllll}1 & 2 & 3 & 4 & 5 & 6\end{array}$

41. Without scientists we would still be living in caves.

$1253 \quad 4 \quad 56$

42. Being a scientist would be fun.

43. Science is responsible for progress.

$\begin{array}{llllll}1 & 2 & 3 & 4 & 5 & 6\end{array}$

$\begin{array}{llllll}1 & 2 & 3 & 4 & 5 & 6\end{array}$

44. A scientist's work is dull.

45. A scientist's work is boring.

$\begin{array}{llllll}1 & 2 & 3 & 4 & 5 & 6\end{array}$

$\begin{array}{llllll}1 & 2 & 3 & 4 & 5 & 6\end{array}$

46. Science is responsible for preserving more lives.

$\begin{array}{llllll}1 & 2 & 3 & 4 & 5 & 6\end{array}$

47. A scientist's work is time consuming.

$\begin{array}{llllll}1 & 2 & 3 & 4 & 5 & 6\end{array}$

48. Science is responsible for improving the health and comfort of the population.

$1 \quad 2 \quad 3 \quad 4 \quad 56$

$\begin{array}{llllll}1 & 2 & 3 & 4 & 5 & 6\end{array}$ 


\section{Appendix 3 \\ Science Siesta Evaluation Summary $(n=127)$}

1. Put the steps of the scientific method in the correct order:

\begin{tabular}{|l|l|l|}
\hline Question & Correct Response Pre & Correct Response Post \\
\hline Develop a hypothesis & $20-16 \%$ & $107=84 \%$ (68\% increase) \\
\hline State your theory & $39=31 \%$ & $118=93 \%$ (62\% increase) \\
\hline Conduct Experiments & $50=39 \%$ & $115=91 \%$ (52\% increase) \\
\hline Make an Observation & $7=6 \%$ & $114=90 \%$ (84\% increase) \\
\hline Ask a question & $20=16 \%$ & $114=90 \%$ (74\% increase) \\
\hline Make predictions & $27=21 \%$ & $110=87 \%$ (66\% increase) \\
\hline
\end{tabular}

2. Why is it important to use the scientific method?

$110=87 \%$ correct response

"It is the best way to separate the things that are true about our world from those that are untrue."

3. The job description and cool fact that best describes each scientist.

Put the letter of the correct response in the appropriate box.

\begin{tabular}{|l|l|l|}
\hline Scientist & Job Description Pre & Job Description Post \\
\hline Analytical Chemist & $38=30 \%$ & $46=36 \%$ ( 6\% increase) \\
\hline Coroner & $58=46 \%$ & $82=65 \%$ (19\% increase) \\
\hline Nuclear Chemist & $27=21 \%$ & $39=31 \%$ (10\% increase) \\
\hline Nurse & $30=31 \%$ & $66=52 \%$ (21\% increase) \\
\hline Pharmacist & $81=64 \%$ & $90=71 \%(7 \%$ increase $)$ \\
\hline Physical Therapist & $46=36 \%$ & $71=56 \%$ (20\% increase) \\
\hline Plant Pathologist & $81=64 \%$ & $87=69 \%(5 \%$ increase $)$ \\
\hline Safety Engineer & $71=56 \%$ & $79=62 \%$ (6\% increase) \\
\hline Veterinarian & $91=72 \%$ & $107=84 \%(12 \%$ increase $)$ \\
\hline
\end{tabular}




\begin{tabular}{|l|l|l|}
\hline Scientist & A Cool Fact Pre & A Cool Fact Post \\
\hline Analytical Chemist & $15=12 \%$ & $39=31 \%$ (19\% increase) \\
\hline Coroner & $18=14 \%$ & $54=43 \%$ (29\% increase) \\
\hline Nuclear Chemist & $33=26 \%$ & $54=43 \%$ (17\% increase) \\
\hline Nurse & $20=16 \%$ & $35=28 \%$ (12\% increase) \\
\hline Pharmacist & $13=10 \%$ & $40=31 \%$ (21\% increase) \\
\hline Physical Therapist & $25=20 \%$ & $71=56 \%$ ( 26\% increase) \\
\hline Plant Pathologist & $23=18 \%$ & $53=42 \%$ (24\% increase) \\
\hline Safety Engineer & $46=36 \%$ & $63=50 \%$ (16\% increase) \\
\hline Veterinarian & $25=20 \%$ & $65=51 \%$ (31\% increase) \\
\hline
\end{tabular}

